\title{
Legal remedies against state funding decisions in Slovakia
}

\author{
Gábor Hulkó*
}

* JUDr. Gábor Hulkó, PhD. is associate professor for administrative law, Széchenyi István University in Győr, Faculty of Law. (e-mail address: gabor.hulko@email.cz)

Abstract: Legal remedies against decisions of central state administration or special administrative bodies instead of the standardly used appeal (which is more or less identical in all Visegrad states) special types of legal remedies step in, which can be still considered as ordinary remedies. In Slovakia, the standard legal remedy in administrative procedures is the appeal (in case of organs of central administration called remonstrance) regulated by Act no. 71/1976 on Administrative Proceedings, however in case of special organs this regulation is often overwritten by special rules and by special legal remedies. Latter mentioned - from a jurisprudential point of view - raising the question, whether they can really serve as a tool for a real legal remedy if they represent an effective tool of decision supervision. The following case study introduces the standard procedure of use of such special legal remedy against a decision of the State Fund for Housing Development in Slovakia.

Keywords: administrative procedure; legal remedies; appeal; remonstrance; suggestion of error; bodies of central administration; state funds

The possibility to defend oneself against the decision of an administrative body is one of the basic principles of administrative procedure. An appeal is a universal tool against an administrative decision in the Slovak Republic; an ordinary legal remedy. The basic regulation of this legal institute is given by Act no. 71/1967 on Administrative Proceedings (Administrative Code). This statue contains the basic principles and rules of administrative procedure, as lex generalis. In the system of the Administrative Code, the ordinary legal remedy is referred to as an 'appeal' or 'remonstrance', depending on whether it is used against central administration bodies or not. Regarding regular administrative organizations, the appeal applies, while in case of groups of central administration, remonstrance is used. The main difference between these two is that remonstrance has no devolutive effect, and according to the regulation (paragraph 61 section 2) 'remonstrance shall be settled by the Chief Officer of the central body of public administration based on the motion of a special committee established by the Chief Officer'. This legal construction in itself raises the question of whether it can guarantee substantive and effective review of a decision, because it is carried out by the same authority which issued the decision in the first instance. Among the Visegrad states, this legal construction can be considered universal, with the exception of Hungary. Hungary, in 
accordance with paragraph 100 Act no. CXL of 2004 on the General Rules of Administrative Proceedings and Services, cannot submit an appeal '...against any decision of the first instance adopted by a minister, by the head of an autonomous government body, an autonomous regulatory agency or other similar government agency;' or '...against any decision of the first instance adopted by the head of a central government body'. In these cases, 'the decision of the first instance may be subject to judicial review'.

The regulation is somewhat different in cases of special procedures. For various reasons, the Administrative Code does not apply to administrative procedures (proceedings in which the rights, the legitimate interests and the duties of the citizens and organizations regarding the public administration are decided), or applies, but only to a minor extent. These procedures are regulated by special laws, which therefore contain special rules exclusively for these procedures, the lex special derogat legi generali rule applies, and the use of the Administrative Code can be excluded partially or completely. The uniqueness of these procedures can be due to numerous factors, such as by the specialty of the organization making the decision. In the case of these procedures, the extent to which basic principles and basic procedural rights (right to legal remedy, fair procedure) apply is always problematic, as generally these special rules do not contain a complex regulation of the given procedure. Alternatively, there has to be a core regulation (mainly concerning principles and basic party rights), which has to be part of every procedure, regardless of its relation to the Administrative Code. For instance, such rule is to be found in the Czech regulation. According to paragraph 177 section 1 of Act no. 500/2004 on Code of Administrative Procedure, in spite of which 'fundamental principles of activities of administrative bodies... shall apply in public administration also in cases where special law provides that Administrative Procedure Code shall not apply but the special law itself fails to contain relevant provisions corresponding with the principles'.

The case in question deals with this kind of special procedure, with the decision-making of state funds, namely the State Fund for Housing Development. State funds in the Slovak Republic are legal persons, constituted by law for financing specialized state tasks (see paragraph 5 of Act no. 523/2004 on Budgetary Rules of Public Administration). State funds are under the supervision of a central state administration body, while their budget is influenced by the Government. State funds can be considered administrative 
bodies in a wider sense, legal persons of public law. State funds often decide on rights, legitimate interests, and duties of the citizens, so in this regard they can be considered as bodies of public administration; sometimes the Administrative Code is applied for their procedures, but in many cases their procedures are regulated by different, special rules.

The State Fund for Housing Development is constituted in Act no. 150/2013 on State Fund for Housing Development (hereinafter as Act on Housing Development Fund). The competence of the Fund for Housing Development (hereinafter as Fund) has its own specialties as well, which must be explained in some extent, according to the actual case, which is concerned with the subsidies granted for local self-municipalities. Local self-municipalities in Slovakia can apply for a subsidy combined from a non-repayable grant and a long-term loan for housing acquisition. The grant is provided by the Ministry of Transport, Construction, and Regional Development of the Slovak Republic (hereinafter as Ministry), while the loan is provided by the Fund. The loan is advanced under favorable terms (a mortgage loan with a 20-30 year duration and a fixed $1 \%$ interest rate). As a thumbnail rule it is valid that the Ministry finances approximately $1 / 3$ of the cost of acquisition, while $2 / 3$ of the price is financed through the Fund's loan. The decision-making of the Ministry is regulated by Act no. 443/2010 on Grants for Housing Development and on Social Housing (hereinafter as Act on Grants for Housing Development), the decision-making of the Fund by the Act on Housing Development Fund. One of the basic conditions of approving the loan is that the applicant did not breach the financial agreement during the disposal with the Fund's financial assets (this refers to previous time periods). Additionally, a basic condition of approving the grant is that the applicant has disposal over the remainder of the acquisition price. In this way, the application for a loan goes hand-in-hand with the application for a grant.

For approving the subsidy (neither for the grant, nor for the loan) there is no legal entitlement, which means, that despite that the applicant fulfills all conditions, his/her application can be rejected. Of course even in these cases, the negative decision cannot be arbitrary - it must be properly reasoned in line with the expectation (or principle) of good administration. The loan can be declined due to the fact that the Fund ran out of its annual budget for this objective or the application failed to fulfill the conditions prescribed by the Act on Housing Development Fund (see paragraph 15 section 19). Legal remedies 
are determined by the Act on Housing Development Fund, which states that against a negative decision a suggestion of error (hereinafter as suggestion) could be submitted within 30 days after the delivery of the decision, while the decision-review is carried out (in another 30 day period, after filing the suggestion) by the Ministry, as the supervisory body.

A particular case deals with the application for a subsidy (grant and loan) of the local self-government Holice, which is a small settlement of approximately 2000 inhabitants in the southwestern region of Slovakia, on Great Rye Island. An application for a grant was to finance the acquisition of 13 housing units, where $30 \%$ was financed from a grant, and $70 \%$ of the price from a loan.

The application was submitted on 15th January 2015, rejected by the Fund's decision on 9th July 2015, with the justification that the applicant breached the budgetary discipline during the disposal with the Fund's financial assets (see above), due to the fact that the annual auditor's report labeled the shortterm liability of the local self-government risky. In other words: the selfgovernment's cash flow was rather low. Based on this decision, the Ministry also refused (23rd July 2015) acknowledgement of a grant, due to the fact that the applicant could not prove the disposal over the $70 \%$ of the acquisition price. Both decisions were filed on 24th July 2015 at the self-government. In this way, the decision of the Fund affected the subsidy as a whole, as the loan and the grant in this case are mutually dependent.

Against the decision of the Fund, a suggestion of error was filed, which is an ordinary-like legal remedy regulated by the Act on Housing Development Fund. The suggestion highlighted that the annual auditor's report cannot serve as a reason for breaching the budgetary discipline. Since the report was positive, the auditor stated no breach of law. It only declares that the selfgovernment's capacity of settling short-term debts has a higher risk factor. Furthermore, low cash flow alone is not enough to fulfill the condition of breaching the financial agreement in accordance with disposal of the Fund's financial assets, as there must be a connection between the low cash flow and the using of (previous) financial assets of the Fund, while this connection simultaneously causes a breach of the Act on Budgetary Rules of Public Administration - otherwise it cannot be considered as breaching the financial agreement. The suggestion was handed over to the Fund on 27th July 2015, the overview was ensured by the Ministry in rejecting the suggestion on 4th September 2015. According to its argument, having a low cash flow alone does 
not mean there was a breach of the financial agreement. However, during the review process it was determined that the local self-government failed to pay on-time the credit installment from previous loans from the Fund, so these late payments can be considered as breaching budgetary discipline.

From a boarder perspective, the procedure is legal, but not flawless in all regards. It is certainly positive, in that in accordance to the principles of legality and material truth, the decision can be changed also to the disadvantage of the applicant. This shows that the suggestion can serve as a tool of objective legal protection. Furthermore, the decision-review does not limit itself only to legality, but also extends to technical issues, and it is quicker when compared to judicial review. On the other hand, this standard procedure has its own issues. Probably the most important among these is the (legal and practical) effect of a successful suggestion - in such case a restitutio in integrum would be in place, so that the applicant should regain his former status and legal position among the other applicants. The problem is that: 1) submitting an suggestion has no delaying effect (the Fund's loans can be approved to other applicant instead), so it can lead to a situation, where the Fund depletes its financial assets for loans meantime and despite the successful suggestion the restitution is de facto impossible; and 2) submitting an suggestion has no effect whatsoever on the Ministry's grant (so the grant can be awarded to another applicant meanwhile), which could lead to a similar situation, because budgetary limitations on grants are serious. From the applicant's point of view, the loan without the grant is practically worthless, and the grant without the loan is legally inaccessible. Additionally, the factual impossibility of the restitutio in integrum cause, that the use of suggestion in this case is mostly formal, so there is a little to no chance of a review favorable for the applicant. In this way the subjective legal protection of the applicant is negligible - and it raises the question of whether a formal guarantee of legal remedy could really serve as an effective tool of decision-overview. 


\title{
B ook reviews \\ Tax Ordinance - Directives on Constituting \\ a New Regulation 1
}

\section{Damien Czudek*}

\begin{abstract}
* Dr Mgr. Damian Czudek, Ph.D., assistant professor, Masaryk University, Faculty of Law, specialized in financial law. (e-mail: damian.czudek@law.muni.cz)
\end{abstract}

The publication Tax Ordinance - Directives on Constituting a New Regulation [Ordynacja podatkowa - Kierunkowe założenia nowej regulacji] was the effort of a team of authors led by Professor Leonard Etel, an expert in the field of tax law, and Chairman of the General Tax Law Recodification Commission [Komisja Kodyfikacyjna Ogólnego Prawa Podatkowego]. This Commission was established in November 2014 in order to prepare and submit to the Council of Ministers complex and systemic changes in Polish tax procedure. Over the next two years, the bill (new act) was to be prepared. During the preparation of the official opinion of the Commission, there were various compromises and modifications when compared to the original draft. Authors therefore decided that they would write and issue their ideas and suggestions regarding new regulations of tax administration in Poland in the form of a currently peer-reviewed monograph. This type of format allows more space for the presentation of various ideas, currently insurmountable for several reasons (whether political or with regard to conservatism).

The current Tax Ordinance [Ordynacja podatkowa] came into effect in 1997. But since the Polish economy has changed and developed over time, and Polish taxpayers and their internationalization have changed with it. It now seems more than appropriate to consider a comprehensive and systematic change in the legal regulation of tax administration. These changes are also necessary for the proper functioning of financial management and efficient tax collection. Keeping this in mind, it is necessary to continue to ensure the fundamental rights of taxpayers. More and more often (and as we see in Czech courts) there is a misunderstanding of the function and role of taxes in the state regarding its fundamental duty - the production of material to ensure the creation of public goods. Taxes are often viewed as quite the opposite, similar 
to restrictions on economic activities of entities operating in the market. This leads to measured and varied interests of the state versus interests of the individual.

The Commission also worked interactively, and during the work partial results were presented, and numerous suggestions from the tax and customs administration were collected. One such example was IX scientific conference 'Ordynacja podatkowa w teorii i praktyce' organized by the Faculty of Law, University of Białystok in the picturesque Augustów, in May 2015.

The book is a compilation of proposals for changes to improve the quality of legislation with regard to its impact on public budgets and the addressees of legal norms-tax subjects. The authors analyzed a number of sources: scientific literature, case law and legal regulation, and were inspired by a wealth of both international experience and foreign regulations. The book contains a number of theories on what the new regulation of tax administration should look like. There are three different opinions and approaches to solving the current problems with the aim to improve the future regulation, but not at the cost of its rigidity and casuistry, but in order to simplify and streamline the system.

This publication is highly recommended. Its concepts and settings of the effective functioning of financial management, with the maintenance and guarantee of taxpayers' rights, makes it a recommended read both for those who are involved in tax procedures, and legislators outside of financial law.

\section{References}

1. Leonard Etel (ed.), Tax Ordinance - Directives on Constituting a New Regulation [Ordynacja Podatkowa. Kierunkowe założenia nowej regulacji] (Białystok, Temida 2, 2015). 


\section{Chapters on Special Public Administration $\underline{1}$}

\section{Júlia Fehér*}

* Dr. Júlia Fehér, PhD student, specialized in administrative law, Széchenyi István University in Győr, Faculty of Law. (e-mail address: juliafmail@gmail.com)

The main aim of the three-volume series, Chapters on Special Public Administration is to place practical public administration into focus. Through creating an awareness-raising presentation of national basic functions, economy, infrastructure, and human public services based on legislature, in a comparative way with historical analyses, and fulfilling the need of course books and professional books as well. It is the first relevant publication in Hungary which attempts a comprehensive analysis and description of as much particular sectors of public administration as possible. For this reason, a nationwide 'work group' was established (the series has over 30 authors) under Editor András Lapsánszky. The volumes are special and unique in this way, because they are also the result of a work group which is characterized by a high degree of professionalism and true collegiality. It is the common, harmonized work of Hungary's departments of public administration and the National University of Public Service.

The relationship of general (general administration) and special public administration (special administration) must be clarified, because of the possibilities of shade and sharp demarcation in the Hungarian doctrinal system. In understanding this system, general administration is indispensable, but the distinction between the two branches is mostly virtual. The system is a theoretical basis and general doctrine of special administration. Therefore the general notional order and structure of public administration is described by the general public administration (science of public administration and legal systemic) - ensuring unity in the more particular world of special administration. The law of special administration focuses on individual sectors of public administration. However, it cannot be separated from the basic notions, apparatus, or procedure of public administration, nor can it be understood in itself, since it cannot be scientifically analysed without the general doctrines. 
As for the theoretical basis, it is important to note that national tasks and functions provide a certain framework for special administration: the activity of authorities belonging to public administration is the route of carrying out state administration. As a result, modern public administration is essentially special administration, as public administration bodies carry out their activities with regards to one sector, in one given area. The rapid improvement of society generates newer and newer needs, and fulfilling them occurs through newer and newer national engagements (therefore, the restrictive listing of tasks is impossible, as it is constantly changing). The realizations of these tasks occur mostly via public administration, in the frame of the modern 'administrative state.' The general aim of nearly all cases is to increase citizens' quality of life and to realize social wealth. $\underline{2}$

The administrative tasks of the state prevail in many areas (and this is by no means an exhaustive list): operation of national economy; health and social insurance administration; social administration (decreasing social differences, labour administration, social net); public education; cultural (human) administration; protection of nature and the environment; consumer protection; transportation administration; communication and media administration; police administration (averting catastrophes, acting against terrorism); energy and industry administration; etc. The volumes elaborate on the most significant branches of special administration, and endeavour to highlight information which conveys the important theoretical basis both for students and professionals, such as: reasons and degree of national intervention; most significant institutions of the sector; relevant legislature; historical characteristics of sectorial administration; international comparative analysis; and regulative models. Therefore the dual objective, so the volumes may serve as course books and special books as well, has been fully realized. Also, it should be emphasized, that the volumes present elaborate on such areas of special public administration which have not been previously discussed in Hungary. While most of the areas explored are rich in literature, in these cases a systematization and a dogmatic unification is carried out.

The theory of organizing special administration chapters into a book can be understood in the wider subject of administration. Based on this, the first volume details the basis of special administration and state functions. It presents the current form of European public administration law, as well as: its expected means of improvement; the system of national registers; the basis of 
police administration and police law; administrative rules referring to foreigners; regulations of the right of asylum; national defence administration; tax and customs administration; judiciary administration; public finance administration; and the special administration basis of e-public administration. The second volume covers economic and infrastructure administration, such as: the administration of the national economy; economic competition; energy and mining administration; water administration; information communications; the construction administration; trade; rules of regional development and area management; administration of environmental protection; the special administration basis of financial services; hunting administration; transportation administration; and the law of national support. The third volume centers on: connections to human administration, such as health law and administration; education; the administrative basis of public education; child protection and social service administration; cultural administration; social administration; and media regulation.

To summarize, these three volumes are professional, accurate, and rooted in law. They are not only interesting, but can be learned, taught, and utilized. They will greatly assist those to better understand such a comparative analysis that takes multiple perspectives, from not only international and European viewpoints, but also from the perspective of students and researchers.

The discovery and understanding of public administration beyond administrative procedure proves to be a serious challenge, but the three volumes of Chapters on Special Public Administration provide an outstanding guide in this endeavour. 


\section{References}

1. András Lapsánszky (ed.), Fejezetek szakigazgatásaink köréből [Chapters on Special Public Administration], vol. I-III. (Budapest, Wolters Kluwer, 2013).

2. Adrián Fábián, Közigazgatás és szakigazgatás [Public administration and special administration], 13, in Lapsánszky András (ed.), Fejezetek szakigazgatásaink köréből [Chapters from our special administration], (Budapest, Wolters Kluwer, 2013). 